\title{
Bosna i Hercegovina u kontekstu aktualnih trendova na relaciji država - religija - pojedinac
}

Nedim Ademović, Hansjörg Schmid, Jens Woelk, Joseph Marko, Drino Galičić, Fikret Karčić, Dino Abazović, Doktrinarni i praktični aspekti odnosa između države, crkava/vjerskih zajednica i pojedinca, Europska akademija za primijenjena istraživanja i obrazovanje u Bosni i Hercegovini, Sarajevo 2012, 98 str.

Sloboda vjeroispovijesti predstavlja jedno od temeljnih ljudskih prava, koje je u svome povijesnom razvoju, praćenim različitim modelima uređenja odnosa između religijskog i političkog autoriteta, te mehanizmima zaštite ovog prava, evoluiralo od neslobode i prinude, preko trpeljivosti i tolerancije, do pune slobode izražavanja vjerskih i svjetonazornih uvjerenja. Razvijanjem koncepta moderne laičke države nakon Francuske revolucije, počevši od 18. stoljeća opservira se proces strukturalnog razdvajanja svjetovne i crkvene vlasti popraćen priznanjem slobode misli, savjesti i vjeroispovijesti svih građana te uspostavljanjem svjetovnog građanskog društva. Tijekom vremena počeli su se javljati raznoliki oblici sekularne države koja je, razdvajajući političku sferu od domene vjere i osobnih uvjerenja, ne privilegirajući nijednu religiju i promicanu koncepciju ispravnog života, garantirala slobodno ispovijedanje svake od njih u zakonski određenim granicama. Ideja svjetovnosti postupno se kristalizirala u načelu vjerske tolerancije, razgraničavanju građanske i vjerske pripadnosti te premještanju legitimiteta države s dominantnih religija na suverenitet naroda, rezultirajući posredno ublažavanjem vjerske diskriminacije i uspostavljanjem društvenog mira. Svjetovna odvojenost građanskih prava od religije te vrijednosni postulat vjerske tolerancije ustanovljeni državnim dekretima i međunarodnim aktima koji danas obavezuju 
u svim demokratskim zemljama, nerijetko su, međutim, u povijesti bili dovođeni u pitanje političkim interesima društvenih grupa uspostavljanih na etno-konfesionalnim osnovama.

Bosna i Hercegovina predstavlja multikulturnu i multireligijsku zajednicu sljedbenika triju velikih abrahamskih religija: kršćanstva, islama i judaizma, među kojima se, nakon tragičnog iskustva građanskog rata 1992.-1995. godine, ponovno nastoji uspostaviti izgubljeno međusobno povjerenje, tolerancija i plodotvorni suživot putem pomirenja i interreligijskog dijaloga utemeljenog na partnersko-prijateljskim odnosima te promicanom načelu jedinstva u različitostima. Činjenica stoljetnog kohabitiranja različitih vjerskih tradicija ponukala je grupu bosanskohercegovačkih autora da u znanstvenoj studiji Doktrinarni i praktični aspekti odnosa između države, crkava/vjerskih zajednica i pojedinca, nastaloj u okviru projekta Sloboda religije i međureligijski dijalog: pojedinac - zajednice - država, osmišljenog i koordiniranog od strane Europske akademije za primijenjena istraživanja i daljnje obrazovanje, pokušaju definirati optimalni pravni i institucionalni okvir za odnose države prema crkvama i vjerskim zajednicama u uvjetima religijskog pluralizma, s posebnim osvrtom na Bosnu i Hercegovinu u kojoj formalna i faktička diskriminacija na nacionalnoj, etno-konfesionalnoj i državno-političkoj osnovi predstavlja nepremostivu prepreku za rekoncilijaciju njezinih naroda i reintegraciju društva. Kako bi osigurali profesionalnost, neutralnost i stručnost pri njegovoj implementaciji, partneri Projekta angažirali su multidisciplinarni ekspertni tim sačinjen od znanstvenika iz Bosne i Hercegovine te inozemstva, koji su problemu institucionalnih odnosa i dijaloga na relaciji država - crkve/vjerske zajednice pristupali iz sociološke (Dino Abazović), komparativno-ustavne (Jens Woelk, Joseph Marko, Nedim Ademović), europsko-pravne (Drino Galičić) i pravno-teološke (Fikret Karčić) perspektive (str. 6).

Konfrontirajući uobičajeno shvaćanje pojma sekularizacije, koje opisujući religiju kao predmodernistički relikt prošlosti predviđa njezinu marginalizaciju i potiskivanje u privatnu sferu života vjernika, s fenomenom religijskog revivalizma i zadivljujućom vitalnosti pretežno islamskih (post) modernističkih pokreta, udruga i organizacija koje se zalažu za utjecajniju ulogu religije u politici i društvu, Hansjörg Schmid u poglavlju naslovljenom kao Religije u pluralnoj Europi daje primjer Bosne i Hercegovine kao zemlje u kojoj usprkos formalnoj odvojenosti države i crkve dolazi do 
širokog preklapanja religijske pripadnosti i etniciteta, a vjerski poglavari i zvaničnici preuzimaju ulogu političkih glasnogovornika bosanskohercegovačkih etno-konfesija, što povezuje sa slabosti nacionalne države (str. 10). Budući da civilno društvo pretpostavlja pluralizam aktera, odnosno postojanje različitih društvenih, kulturnih, političkih i vjerskih interesa i ideja, te njihovo pravo da se slobodno očituju i organiziraju, s obzirom na taj pluralizam religije po njegovu mišljenju ne mogu autoritarno propagirati svoje pozicije, već se argumentirano i diskurzivno trebaju uključivati u javne prostore u kojima djeluju konkurirajuće instance kooperirajući s drugim akterima civilnog društva izvan općeprihvaćenih ingerencija religije (str. 14). U situaciji u kojoj se na Starom kontinentu opservira jačanje populističkih glasova koji se u različitim konstelacijama odlikuju ksenofobijom, antisemitizmom i islamofobijom, značaj Bosne i Hercegovine kao zemlje koja iza sebe ima dugo iskustvo zajedničkog života židova, kršćana i muslimana dodatno dobiva na značenju u vidu paradigme plodotvornog suživota sljedbenika različitih vjerskih tradicija u pluralističkom društvu. Iz tog razloga europske zemlje i Europska unija po navodima autora ne bi smjeli prepustiti Bosnu i Hercegovinu samoj sebi, već trebaju učiniti sve što je u njihovoj moći kako se njezini građani deklarirajući pripadnost Europi ne bi osjećali zaboravljeni, neshvaćeni i neprihvaćeni na tamnoj strani Starog kontinenta, što se posebice tiče bosanskohercegovačkih muslimana, koji su često morali iskusiti kako je to biti rastrzan između dviju strana - $\mathrm{u}$ islamskom svijetu nepriznavani kao pravi muslimani, a od strane Europljana kao pravi Europljani - snoseći posebnu odgovornost da potiču i partnerski prate dijalog u oblasti civilnog društva, čemu također treba služiti i ova publikacija (str. 15).

Navodeći postulat slobode vjeroispovijesti kao jedno od najstarijih prava čovjeka u bliskoj vezi s modernim konceptom države koju karakterizira odvajanje svjetovnih i vjerskih vlasti uz jamstvo zaštite manjina, debatirajući o modelima uređenja relacija između države, crkava i religijskih zajednica, Jens Woelk i Nedim Ademović daju kratak uvid u obvezujuće principe uređivanja odnosa između javne vlasti i vjerskih organizacija u kontekstu procesa kontinuirane i progresivne sekularizacije društva, čija je univerzalnost i neminovnost nakon hladnoratovskog razdoblja dovedena u pitanje reafirmacijom vjerskog čimbenika koji je $u$ današnje vrijeme ponovno dobio centralni politički i ideološki značaj (str. 18). Dok 
je u (zapadno)europskoj državnopravnoj tradiciji strukturalno odvajanje države i crkve provođeno sustavno i skrupulozno, uz izvjesne razlike koje su proistjecale iz različitog društvenog, političkog i gospodarskog razvoja pojedinih zemalja rezultiravši stanovitim konceptualnim i funkcionalnim odstupanjima u područjima njihova utjecaja, nadležnosti i djelovanja, u drugim kulturnim tradicijama, a posebice na područjima pod utjecajem islamske civilizacije, proces sekularizacije društva i eliminacije religijskoga utjecaja na državu nikada nije u potpunosti sproveden, već su svjetovne i vjerske vlasti ostajale simbiotski srasle, isprepletene i povezane s šerijatom kao jednim od temeljnih izvora pozitivnog prava (str. 17-18). Kao nužan preduvjet za institucionalno poštivanje slobode izražavanja vjerskih i svjetonazornih uvjerenja autori ističu prethodno zakonsko priznavanje relevantnih vjerskih zajednica, kojim im se iz perspektive pravnog sustava države daje status subjekta različitog tretmana ili zaštite, navodeći pri tom četiri opća modela koja im stoje na raspolaganju: konfesionalni, agnostički, multikonfesionalni i stimulativni sustav utemeljen na konkordatu (str. 18-19), pri čemu su bosanskohercegovačkim uvjetima primjenljiva isključivo posljednja tri. Premda se u Ustavu Bosne i Hercegovine ne mogu pronaći eksplicitna pravila o razdvajanju crkve i države i/ili jednakosti različitih vjeroispovijesti i vjerskih zajednica, republikanski oblik ustavnopravnog ustroja države implicite podrazumijeva njezin sekularni karakter, uslijed čega bi se uvođenje konfesionalnog principa odnosa javne vlasti i vjerskih zajednica u Bosni i Hercegovini prema sudu autora kosilo s temeljnom postavkom njezinog ustavnopravnog uređenja negirajući sekularnost države kao takve (str. 23-24).

Suprotno predviđanjima marginaliziranja uloge religije u javnoj i političkoj sferi života iz razloga sekularizacije države i društva, svjedoci smo njezina povratka u ulozi relevantnog sociokulturnog i ideopolitičkog čimbenika kao posljedice vraćanja onim vrijednostima koje su u procesu modernizacije bile potisnute na periferiju društvenih tokova, što je za posljedicu, između ostalog, imalo također iniciranje diskursa o percepciji i uporabi religijskih simbola u različitim društvenim sferama, čime se bavi Joseph Marko u narednom poglavlju ove studije naslovljenom kao Vjerska obilježja i simboli, elaborirajući pitanje pripisanog im statusa u ustavnopravnim okvirima. Analizirajući aktualnu situaciju u sve više sekulariziranom i istovremeno sve više religijski pluraliziranom europskom društvu, 
autor konstatira evidentnu reafirmaciju uporabe vjerskih simbola u javnoj i političkoj sferi, koja je početkom 21. stoljeća pokrenula diskusiju o pravu na iskazivanje religijske pripadnosti putem vjerskih simbola, te njegovu adekvatnom razgraničenju - ne samo od drugih ljudskih prava i temeljnih sloboda, već također od države i njezine sekularnosti (str. 27). U potrazi za odgovorom na pitanje dokle seže sloboda isticanja vjerskih obilježja u sekularnoj državi, kao jedan od elemenata zajamčene slobode izražavanja vjeroispovijesti, te kako normiranjem njihove uporabe očuvati pluralizam vjerskih i svjetonazornih uvjerenja karakterističan za suvremeno društvo, autor nudi niz konkretnih primjera načina na koji se europski pravni sustavi sučeljavaju s jednim od najvećih izazova suvremene demokracije (str. 28-32), izdvajajući u konačnici dva osnovna modela rješavanja pitanja njihovog korištenja u javnom prostoru. Prvi od njih naziva modelom „,negativne jednakosti“ opisujući ga kao sustav koji, po njegovu sudu, ustavnopravno sankcionira manifestiranje religije i vjerskih simbola u javnosti navodno osiguravajući ,ekvidistancu” između države i religija/crkava na temelju „mita o neutralnosti” države i državnih tijela s primarnim ciljem „sprječavanja” sukoba na osnovu religijske motivacije i političke mobilizacije vjernika te ga konfrontira s modelom ,pozitivne jednakosti” koji nije utemeljen na ideji striktne institucionalne odvojenosti državnog/javnog prostora od religije, ali dozvoljava različite vidove gradacije suradnje između države i crkava, obrazujući takozvani forum externum slobode religije, odnosno ,javni prostor" za akomodaciju vjerskih različitosti, na temelju uzajamnog priznavanja i poštovanja, dijaloga i usavršavanja tolerancije u skladu s Europskom konvencijom o ljudskim pravima kao uvjet načela (religijskog) pluralizma (str. 31). Budući da spomenuta konvencija nema obvezujući karakter, ne postoji jedan usklađen europski standard reguliranja statusa vjerskih obilježja i simbola, već svaka država pronalazi vlastiti put kroz proces političkog donošenja odluka u skladu s distinkcijama koje treba praviti među kulturom i religijom, kao i između državne/javne i privatne sfere (str. 31), pri čemu ni Bosna i Hercegovina ne predstavlja izuzetak. U zemlji u kojoj je na snazi ,teritorijalna kompartmentalizacija" slobode vjeroispovijesti uz diskriminiranje ostalih u svim sferama života uslijed sveprisutnog političkog pritiska koji proistječe iz svojevrsne simbioze političkih stranaka i vjerskih zajednica, najvažniji preduvjet za uvođenje vjerske akomodacije kao instrumenta djelotvorne 
zaštite manjina, prema mišljenju autora, predstavlja prevladavanje problema u svezi s teritorijalnim i etno-vjerskim identitetom te uspostavljanje institucionalnih metoda i sredstava ,kulturne autonomije” u obrazovanju, medijima i u drugim područjima za koje zajednice i njezini lideri smatraju da su važni za očuvanje njihovih kulturnih identiteta (str. 33).

Odabravši za predmet svojega istraživanja problematiku financiranja i imovine vjerskih zajednica u Europi, s posebnim osvrtom na situaciju u Bosni i Hercegovini, nakon uvodne opaske da u širokom rasponu odnosa između države i crkve ovo pitanje predstavlja jedno od najsloženijih i najosjetljivijih, Drino Galičić daje analizu komparativnih iskustava modernih zapadnih demokracija u oblasti financiranja i imovinskih prava crkava/vjerskih zajednica od strane države, sagledavajući normativni okvir i praksu u europskim zemljama i nudeći neka konkretna rješenja koja se mogu primijeniti u bosanskohercegovačkim uvjetima. Temeljno polazište za financijske i sve druge međusobne odnose između javnih i crkvenih vlasti države zapadne demokracije, prema navodima autora, nalaze u promoviranju načela odvojenosti crkava/vjerskih zajednica od države koje, s jedne strane, podrazumijeva samostalno i neovisno djelovanje države uz podređenost crkve/vjerske zajednice državnopravnom poretku, a s druge strane obvezu države da osigura slobodu vjeroispovijesti svim građanima stvaranjem pravne pretpostavke za njezino ostvarenje (str. 41). Najčešći oblici financiranja vjerskih zajednica za koje se opredijelila većina (zapadno)europskih zemalja, a oslanjaju se prvenstveno na model autonomije crkava u institucionalnom smislu, predstavljaju sustav crkvenih poreza, vlastiti prihodi, donacije, financiranje iz državnog budžeta, sustav crkvenih fondacija, doprinosi, stipendije i prikupljeni novac (str. 42). Opisujući u nastavku aktualnu situaciju u Bosni i Hercegovini glede razmatrane problematike, nakon što je konstatirao nedostatak preciznog ustavnopravnog i sociopolitičkog pozicioniranja crkava i vjerskih zajednica u demokratskom bosanskohercegovačkom društvu, autor navodi neke najvažnije pravne akte države iz kojih se posredno mogu izvesti propisi na temelju kojih je regulirano pitanje financijskih odnosa i državne imovine u odnosu na crkve i vjerske zajednice. Pri tome se prvenstveno skuplja na Ustavu Bosne i Hercegovine, a konkretno na člancima u kojima se propisuje sloboda vjeroispovijesti, pravo na obrazovanje, pravo na imovinu i zabrana diskriminacije na temelju vjere, te Zakonu o slobodi vjere i pravnom položaju 
crkava i vjerskih zajednica u Bosni i Hercegovini koji nalaže odvajanje crkve i države isključujući uspostavu modela službene religije, pri čemu država može na temelju jednakosti prema svima davati materijalnu potporu crkvama i vjerskim zajednicama za očuvanje kulturne i povijesne baštine, zdravstvene djelatnosti, obrazovne, karitativne i socijalne usluge, pod uvjetom da spomenute usluge obavljaju bez diskriminacije na osnovu vjere ili uvjerenja (str. 47-48).

Spomenuti pravni akti poslužili su također Jensu Woelku kao polazišna osnova za komparativnu analizu ustavnih temelja i pravne situacije u Bosni i Hercegovini u usporedbi sa stanjem u inim pravnim sustavima u Europi glede religijske naobrazbe u sustavu obrazovnih ustanova, na temelju koje trebaju biti formulirane mjerodavne preporuke za definiranje standarda religijske naobrazbe u obrazovnom sustavu Bosne i Hercegovine, uzimanjem u obzir postignutog konsenzusa o glavnim pitanjima u pogledu vjerskog obrazovanja, kao i mišljenja sudionika organiziranih radionica o toj problematici (str. 61). Autor ustvrđuje da u bosanskohercegovačkom obrazovnom sustavu nema eksplicitnih ustavnih odredbi u pogledu religijske naobrazbe, indicirajući neophodnost izvođenja prikladnih pravnih postavki za odabir odgovarajućeg modela religijskog obrazovanja u javnim školama iz obvezujućih državnih i međunarodnih zakonskih akata. Republikanski princip ustroja Bosne i Hercegovine prema njegovim navodima podrazumijeva sekularno razumijevanje države, drugim riječima odvojenost države od crkve i princip njezine religijske neutralnosti, što znači da koncept zajedničkog javnog interesa nije zasnovan na vjerskim i/ili ideološkim ,višim istinama” i nijedan sustav vjerovanja nema monopol na istinu (str. 62). Europska konvencije za zaštitu ljudskih prava i temeljnih sloboda obvezuje ipak državu da u obavljanju svojih funkcija povezanih s odgojem i poučavanjem poštuje pravo roditelja da osiguraju odgoj i poučavanje u skladu s vlastitim vjerskim i filozofskim uvjerenjima ustanovljavanjem takvoga modela obrazovanja u javnim školama koji bi sprječavao protekciju, indoktrinaciju i diskriminaciju, učeći na neutralan i nepristran način međusobnoj toleranciji, razumijevanju i poštivanju specifikuma pluralističkog karaktera bosanskohercegovačkog društva održavajući vjersku harmoniju i javni red (str. 63).

Pitanjem institucionalnih odnosa na relaciji pojedinac - vjerske zajednice - država bavi se također Fikret Karčić, sagledavajući problem 
u kontekstu procesa uspostavljanja religijskih ustanova i mehanizama uređenja njihovih odnosa s državom na čijem teritoriju djeluju, posvećujući pri tom posebnu pažnju formalnopravnom statusu muslimanskih manjina u zemljama članicama Europske unije, čija specifična situacija proistječe iz činjenice da su, za razliku od pripadnika kršćanskih konfesionalnih zajednica institucionaliziranih u obliku crkava, vjernici islamske vjeroispovijesti organizirani u vjerske zajednice u kojima nema razlikovanja klera i laikata, već se govori o učenjacima i vjernicima (str. 81). U europskim se okvirima prema mišljenju autora pitanje institucionalizacije islama postavlja prvenstveno iz tog razloga, jer u islamskim zemljama iz kojih većinom potječu muslimanske imigrantske zajednice u Europi nikada u potpunosti nije izvršeno odvajanje religijskog i političkog autoriteta, uslijed čega europski muslimani kao preduvjet za uspostavljanje odnosa s državom najprije moraju izgraditi svoje religijske ustanove, pri čemu dodatnu prepreku predstavlja činjenica da se radi o izrazito heterogenoj skupini - jednako tako kada je riječ o teološkom i vjersko-pravnom tumačenju islama, kao i intenzitetu prakticiranja islamskih normi, budući da je sačinjavaju pripadnici mnoštva različitih rasnih, etničkih i jezičnih zajednica (str. 82). Nakon kratkog pregleda aktualnog stanja u pojedinim zemljama članicama Europske unije glede pripisanog pravnog statusa islama u okviru općih odnosa između države i religije, kao i osnivanja različitih muslimanskih ustanova i organizacija s funkcijom vjerskog vodstva, čuvanja, razvijanja i prijenosa znanja te omogućavanja obavljanja religijske prakse, autor zaključuje da institucionalni status islama još nije jedinstveno riješen, već je to izvršeno u okvirima nacionalnih zakonodavstava zemalja članica na taj način što se svaka od država rukovodila vlastitim povijesnim, pravnim i političkim razlozima (str. 86).

Kao autor završnog poglavlja znanstvene studije Doktrinarni i praktični aspekti odnosa između države, crkava/vjerskih zajednica i pojedinca, Dino Abazović započinje svoja Zaključna razmatranja od tvrdnje da u suvremenim demokratskim društvima koja odlikuje razdvajanje države i crkve, načelo sekularizma ne predstavlja opoziciju religiji niti antireligijsku laicizaciju društva, već političku refleksiju na realije života u višereligijskom globaliziranom svijetu koja za polazište ima zaštitu neotuđivih prava individualne svijesti u najdemokratskijoj maniri (str. 95). Rekapitulirajući prethodno elaborirana promišljanja sudionika projekta naslovljenog 
kao Sloboda religije i međureligijski dijalog: pojedinac - zajednice - drža$v a$, za čiju se realizaciju prema navodu uvodničara studije Nedima Ademovića ideja pojavila kao neposredna posljedica istinskih potreba multinacionalnog, multikulturnog i multikonfesionalnog bosanskohercegovačkog društva koje se nalazi u dubokoj i permanentnoj političkoj, gospodarskoj i sigurnosnoj krizi (str. 5), autor sumira glavne teze iz prethodnih elaborata upotpunjujući ih nekim svojim zapažanjima, identificirajući temeljnu ideju vodilju koja se provlači kroz sva tematska poglavlja studije kao nasušnu potrebu za definiranjem i uspostavljanjem odgovarajućeg ustavnopravnog, sociokulturnog i društvenopolitičkog okvira za reguliranjem odnosa države, crkava i vjerskih zajednica u realijama postdaytonske Bosne i Hercegovine kao jamca njezine opstojnosti. Iznađeni model zakonskih okvira za plodotvorni suživot predstavnika različitih religijskih tradicija u ozračju dobrosusjedskih odnosa s visokim stupnjem razumijevanja, tolerancije i međusobnog uvažavanja, poslužio bi kao paradigma za (post)moderni svijet, čija je jedna od najvažnijih odlika identitetski pluralizam.

Predočena publikacija grupe autora predstavlja zanimljivo štivo vrijedno pozornosti, jednako tako za potencijalne čitatelje koji bi se željeli podrobnije informirati o postojećim modalitetima uređenja međusobnih odnosa države, crkava/religijskih zajednica i pojedinaca u (zapadno)europskoj jurisprudenciji i (ne)posrednim konsekvencama njihova implementiranja u kontekstu (ne)poštivanja ljudskih prava i temeljnih sloboda, kao i za one koji nastoje saznati nešto više o aktualnoj situaciji u Bosni i Hercegovini, koju karakterizira interakcija vjere i politike na formalnopravnom i institucionalnom planu pri teritorijalnoj kompartmentalizaciji slobode vjeroispovijesti praćenoj notornim diskriminiranjem manjinskih religijskih zajednica. Interdisciplinarni karakter studije doprinosi potpunijem uvidu u kompleksnost razmatrane problematike proširujući krug odabiratelja, čemu također služe priloženi rezultati anketnih upitnika na četirima definiranim tematskim oblastima od općedruštvenog značaja: sustavu obrazovanja i religijskom podučavanju, financijskim odnosima i državnoj imovini, vjerskim obilježjima i simbolima te institucionalnim odnosima i dijalogu s posebnim osvrtom na islamska vijeća u državama članicama Europske unije, provedenih u okviru organiziranih radionica s udjelom članova stručnog tima oformljenog od strane partnera Projekta, u koji su se, osim inicijatora Europske akademije za primijenjena istraživanja i daljnje 
obrazovanje, uključili također Institut za društvena istraživanja Fakulteta političkih nauka u Sarajevu, Fondacija „Konrad Adenauer” i Deutsche Gesellschaft für Internationale Zusammenarbeit te relevantnih predstavnika crkava, vjerskih zajednica, državnih institucija i civilnog sektora simbolično nazvanih ,prijateljima Projekta”, između ostalih Islamske vjerske zajednice, Srpske pravoslavne crkve, Jevrejske zajednice u Bosni i Hercegovini, Rimokatoličke crkve, Centra za ljudska prava Univerziteta u Sarajevu, Vlade Federacije Bosne i Hercegovine, Udruženja „Vaša prava” te Ministarstva za ljudska prava i Ministarstva pravde Bosne i Hercegovine, a potom primijenjenih od strane eksperata pri izradi znanstvene studije na odabrane teme. Kao izraz spremnosti suradnji pri njegovoj realizaciji, potpisivanjem ,memoranduma o razumijevanju” svi partneri i prijatelji Projekta obvezali su se da će pozitivno doprinositi ostvarenju postavljenih projektnih ciljeva ,težeći političkoj, ekonomskoj i kulturnoj rekonstrukciji i pomirenju nakon godina teških iskušenja iz nedavne prošlosti, (...) s ciljem stvaranja prostora za kvalitetnije međusobno razumijevanje i uvažavanje, te poštivanje prava svih u duhu europskih vrijednosti i u širem kontekstu europskih integracija na ovim prostorima" (str. 7), čemu načelno treba služiti i elaborirana publikacija kao ,prvi korak u nastojanju da Projekt zaživi i praktično se iskoristi” (str. 8). 